\title{
О типах ритма и приемах ритмовки в русском языке
}

\author{
ВАСИЛИЙ МОСКВИН \\ Волгоградский государственный социально-педагогический университет, \\ пр. В. И. Ленина, д. 27, RU-400066 Волгоград \\ E-mail: vasmoskvin@yandex.ru
}

(Received: 30 January 2016; accepted: 23 March 2016)

\begin{abstract}
The present paper provides a critical analysis of the controversial moments of the theory of speech rhythm as well as the history of the issue. The author classifies the types of rhythm and the basic ways of rhythmization. The definition of rhythm is also specified, and the sources for the inner rhythm relevant for accentual syllabics (e.g. foot-based segmentation, caesura, etc.) are considered. In the second part of the paper, the typology of caesuras and the means to mark them is presented.
\end{abstract}

Keywords: the Russian language, rhythm, isocolon, rhythmical period, caesura

\section{о. Введение}

В научной литературе разных лет существует немало различных, порою несовместимых трактовок понятия ритм, в связи с чем специалисты указывают на связанные с ним дефиниционные трудности: «Понятие ритма представляется чрезвычайно сложным для определения» (BOURASSA 1993: 21), на смысловую размытость термина ритм: «Данный термин (как и его кузен метр) очень неясен. На протяжении многих лет он используется применительно к такому числу различных понятий, что тот, кто в настоящее время намерен писать о ритме, должен сначала определить его» (COOPER 1998: 16); Р. Якобсон характеризует данный термин как «несколько двусмысленный» (Якобсон 1975: 213). Причина дефиниционных сложностей видится, в частности, в том, что понятия ритма и метра обсуждаются как связанные исключительно с одним только ударением. Приведем типовую в этом плане схему описания: «В основу моделей метра положен характер чередования интенсивно ударяемых слогов со слабо ударяемыми. Такие модели метра называются стопами. Основные их типы следующие. Ямб состоит из одного слабо ударяемого слога, предшествующего интенсивно ударному слогу. [...] Хорей есть противоположность ямба...» (НовSBAUм 1996: 1). Такая схема имеет глубокие корни. Так, Аристотель характеризует указанные понятия следующим образом: «Речь должна нести ритм, но не метр, иначе получатся стихи. [...] Из ритмов героический ритм [т. е. гекзаметр - В. М.] возвышен и с гармонией связан, ямб же пригоден для разговора большинства, поэтому в их речи почти всегда слышится звучание ямба. Недостает ему, однако, торжественности. Хорей более приличествует разгульному танцу, что видно по тетраметрам, ибо тетраметры - быстрые ритмы...» (ARISTOTELIS 1833: 178). Дио- 
нисий Галикарнасский связывает ритм с понятиями ударения, стопы, слога, арсиса и тесиса (DIONYSII 1774: 1101), видя в основе ритма «омотонию и омо-

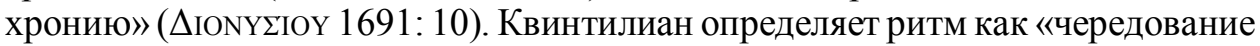
долгих и кратких [т. е. ударных и безударных - В. М.] слогов, из коих стопы складываются» (QUINTILIANI 1725: 601). По мнению Гефестиона, ритм «из шума появляется»: так, он слышится и «из-под молота кузнеца», и «из-под

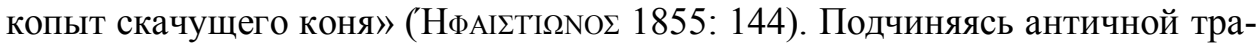
диции, ученые Нового времени понимают под ритмом «симметричное расположение и возвращение сильных и слабых мест в стихах» (MEILLET 1923: 19), «варьирование сильных и слабых мест» (DESSONS-MESCHONNIC 1998: 33), «peшетку уплотнений» (CERIANI 1988: 37); по определению В. Е. Холшевникова, ритм есть «усиление - ослабление, удар - пауза» (Холшевников 1991: 209).

Между тем, в различных языках применяется три типа ритмовки: 1) синтаксическая, 2) силлабо-тоническая и 3) силлабическая; с ударением связан только второй тип. Рассмотрим их в указанной последовательности.

\section{1. Синтаксический ритм}

Синтаксический ритм, или колонритм (нем. Kolonrhythmus) возникает в результате членения речи на соразмерные, т. е. близкие по слоговому объе-

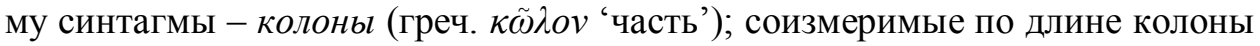
составляют ритмический период (греч. лєріобоऽ 'оборот'). Фигура такого

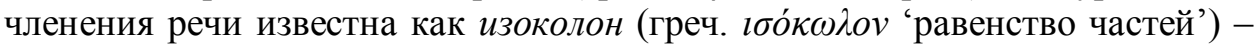
«прием, выражающий законченную целую мысль ритмически, т. е. членением на равные части» ('ЕРмогеNOYг 1834b: 1243).

Количественный минимум синтаксической ритмовки, а значит, и количественный минимум периода образуют два колона:

(1) Делу время, потехе час.

(Поговорка)

В «Риторике к Гереннию», ранее приписываемой Цицерону, читаем: «Из двух членов красивый период может состоять, но удобнейший и совершеннейший - тот, который состоит из трех» (CICERONIS 1828: 300):

(2) И был вечер, и было утро: день один.

(Бытие, 1:5)

Эта количественная трактовка вступает в конфликт с традиционным пониманием периода как сверхсложной фразы: так, Р. Ланхэм сравнивает период с «огромным правильно устроенным парком при дворце в стиле Барокко, где все части симметричны, а дорожки параллельны друг другу» (LANHAм 2003: 49). Существует мнение, что количественный максимум периода составляет четыре колона: «Тот оборот, что периодом греки назвали, чаще два Колона, кои описаны выше, и даже четыре включает; Меры сией 
превышение редко, однако, встречаем» (Carmen 1863: 63-64). Трактовка оптимальной длины периода как состоящего из трех колонов, а максимальной из четырех представляется справедливой по отношению к устной речи, учитывая известные ограничения в ее восприятии и производстве. Скептическое

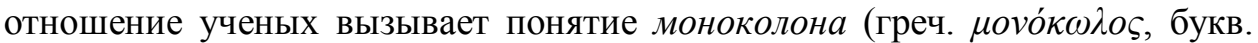
'одноногий'): «Многие полагают, что период может состоять из одного колона; такой период именуют моноколоном. Однако я эту единицу не могу назвать периодом, ибо колон, если он один, не в силах период составить» (AQUILAE 1863: 28). Один моноколон действительно не может создать период как ритмическую единицу, однако их ряд вполне способен стать источником синтаксического ритма:

(3) Азарт благороден. Риск минимален. Выигрыш огромен.

(Реклама лотереи «Русское лото»)

Использование периодов, расчлененных на соизмеримые колоны, создает, по образному выражению Иоанна Цециса, «геометрию речи» (TZETZIS 1837: 138). По аналогии с геометрическими фигурами период, составленный из симметричных колонов, называли «равнобедренным» (греч. $\iota \sigma o ́ \pi \lambda \varepsilon v \rho o v),{ }^{1}$ период из четырех колонов - квадратным, из пяти и более - кругльлм. Синтаксический ритм имеет характер «квазиметра» (CICERONIS 1824: 251), «ритмоида», т. е. ритма неявного, «припрятанного особыми сочетаньями колонов и слов» (АнмнтРіOY 1743: 122). Рассмотрим фрагмент известной былины:

(4a) В славном великом Нове-граде

(4b) А и жил Буслай до девяноста лет.

(4c) С Новым-городом жил, не перечился,

(4d) Со мужики новогородскими

(4е) Поперек словечка не говаривал.

(Про Василья Буслаева)

Такая ритмовка характерна для начальных стадий народного стихосложения. Строчки в подобных стихах (4a - 9 слогов, 4b, 4c, 4e - 11, 4d - 10) различны «и по числу слогов, и по расстановке ударений» (ТиМОФЕЕВ 1958: $185)$, т. е. для стихов, основанных на синтаксической ритмовке, «необязательно абсолютное равенство частей» (GOODELL 1901: 59). Синтаксический ритм усиливается:

1) при маркировке финальных частей колонов звуковыми повторами, в частности, рифмой; данная тактика лежит в основе рифмованной прозы:

(5) А мне, государь, тульские воры выломали на пытках руки и нарядили, что крюки, да вкинули в тюрьму, и лавка, государь, была узка, и взяла меня великая тоска, а постлана рогожа, и спать не погоже.

(Ив. Фуников: Послание дворянина к дворянину - нач. XVII в.)

\footnotetext{
${ }^{1}$ Асимметрия колонов считалась композиционным недостатком периода (vituium periodi).
} 
2) при сближении колонов: а) по числу слогов; б) по структуре, например, за счет синтаксического параллелизма:

(6) Вернуть нельзя, забыть невозможно.

(Эпитафия)

На синтаксический параллелизм могут накладываться:

а) лексический повтор; комбинация этих двух фигур лежит в основе гипозевксиса (греч. vंло́ $\varepsilon v \xi \xi \varsigma$ ‘снятие зевгмы'):

(7) Все течет, все меняется. ${ }^{2}$

(Поговорка)

б) морфемный, звуковой и силлабо-тонический параллелизм (изотония), в результате чего речевые единицы становятся «изосиллабичны, изотоничны, изосинтаксичны и изохроничны» (SCHILLER 1961: 23), ср.:

(8а) Уутихает светлый ветер, Наступает серьй вччер.

(А. Блок: Утихает светлый ветер...)

(8b) С Йльным - работу, слабабм - заботуу!

(Предвыборный лозунг)

Здесь подчеркнем, что ни повторы, ни, в частности, параллелизм не являются обязательным атрибутом синтаксической ритмовки.

\section{2. Силлабо-тонический ритм}

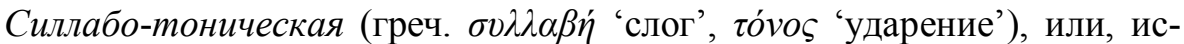

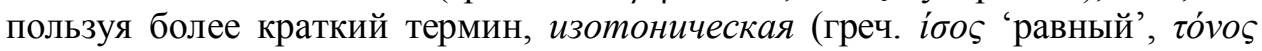
'ударение') ритмовка основана на симметричном чередовании ударных и безударных слогов. Расстановка ударений происходит в этом случае через равные слоговые интервалы: 1) через один слог, начиная с первого (хорей) или второго (ямб); 2) через каждые два слога, начиная с первого (дактиль), второго (амфибрахий) или третьего (анапест). По длине метры подразделяются на два типа: 1) краткие (ямб и хорей), придающие речи ускоренный темп; 2) долгие (дактиль, амфибрахий и анапест), замедляющие темп речи. По акцентной структуре различают: 1) восходящие метры (см. 9а), начинающиеся с безударного слога (анапест, ямб и амфибрахий); 2) нисходящие (9b), начинающиеся с ударного слога (хорей и дактиль). Восходящие метры трактуются как мажорные по настроению, нисходящие - как минорные, ср.:

\footnotetext{
2 Замена гипозевксиса так называемой простой зевгмой приводит к снижению стиля и утрате выразительной силы, ср.: Все течет и меняется.
} 


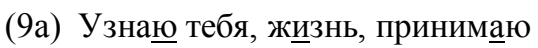

И приветствую звоном щита!

(А. Блок: О, весна без конца и без краю...)

(9b) Вырыта заступом яма глубокая,

Жизнь невеселая, жизнь одинокая...

(И. Никитин: Вырыта заступом яма глубокая...)

Стремясь придать музыкальность прозаическому тексту, авторы нередко прибегают к его частичной или сквозной изотонической ритмизации; так

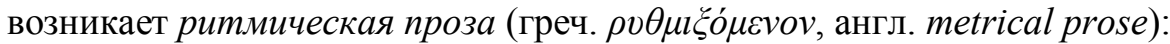

(10) Синие горы Кавказа, приветствую вас! вы взлелеяли детство мое; вы носйли меня на свойх одичалых хребтах

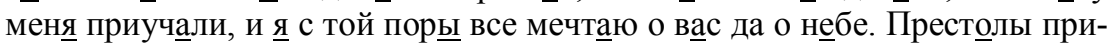
роды, с которых как дым улетают громовые тучи, кто раз лишь на ваших вершинах творцу помолился, тот жизнь презирает, хотя в то мгновенье гордился он ею!..

(М. Ю. Лермонтов: Синие горы Кавказа, приветствую вас!)

Изотоническая ритмовка характерна для языков с разноместным ударением, которое делает возможными все пять метрических типов (хорей, ямб, дактиль, амфибрахий и анапест), в языках с фиксированным ударением допустимы лишь два из этих пяти: так, во французском, где ударение приходится на последний слог, невозможны хорей, дактиль и амфибрахий; в венгерском, где ударным может быть лишь первый слог, нет ямба, анапеста и амфибрахия; в польском, в словах которого всегда ударен предпоследний слог, исключены ямб, дактиль и анапест, см. Таблицу 1:

Таблица 1. Распределение метрических типов по акцентным типам языков

\begin{tabular}{|c|c|c|c|c|c|c|}
\hline \multirow{2}{*}{\multicolumn{2}{|c|}{}} & \multicolumn{5}{c|}{ Язтрические типы } \\
\cline { 3 - 7 } & Хорей & Ямб & Дактиль & Амфибрахий & Анапест \\
\hline \multirow{4}{*}{$\begin{array}{c}\text { С подвижным } \\
\text { ударением }\end{array}$} & Русский & + & + & + & + & + \\
\cline { 2 - 7 } & Английский & + & + & + & + & + \\
\cline { 2 - 7 } & Немецкий & + & + & + & + & + \\
\hline \multirow{2}{*}{$\begin{array}{c}\text { С фиксиро- } \\
\text { ванным } \\
\text { ударением }\end{array}$} & Французский & - & + & - & - & + \\
\cline { 2 - 7 } & Венгерский & + & - & + & - & - \\
\cline { 2 - 7 } & Польский & + & - & - & + & - \\
\hline
\end{tabular}

Исторически изначальной представляется синтаксическая ритмовка, затем в дополнение к ней в языках с фиксированным ударением возникает силлабическая, в языках с разноместным ударением - изотоническая ритмовка.

Как отмечено выше (см. Введение), по традиции, восходящей к Аристотелю, учение о ритме сводится к одному из трех его типов - силлабо-тониче- 
скому. Однако Аристотель пришел к выводам относительно типов ритма на основании реалий только древнегреческого, т. е. языка с разноместным ударением, поэтому соответствующие античной традиции определения категории ритма через понятия стопы и ударения, предлагаемые современными специалистами, выглядят как saltus in concludendo.

\section{3. Силлабический ритм}

В языках с неполной изотонической парадигмой используется преимущественно силлабическая ритмовка, возникающая в результате подравнивания стихов по числу слогов. Приведем мнение А. Х. Востокова: «Силлабическое стихосложение есть изобретение поздних времен и выдумано по нужде для тех языков, коих прозодия ограничена неизменяемостью ударений на одном котором-нибудь слоге; так, например, в польском всегда на предпоследнем, а во французском на последнем слоге ударение. Сия ограниченность не позволяет им размерять стихи свои по стопам» (Востоков 1817: 65-67). Рассмотрим первый катрен сонета Адама Мицкевича «Байдарская долина»:

(11) Wypuszczam na wiatr konia i nie szczędzę razów;

Lasy, doliny, głazy, w kolei, w natłoku

U nóg mych płyną, gina, jak fale potoku;

Chcę odurzyć się, upić tym wirem obrazów.

(A. Mickiewicz: Bajdary)

Длина каждого стиха составляет 13 слогов, концовка каждого отмечена женской рифмой. В переводе А. Н. Майкова (см. 12) акцентная аритмия силлабики преобразована в ямб, первая и четвертая женские рифмы по правилу рифменного альтернанса (т. е. для преодоления рифменной монотонии) заменены мужскими, а значит, симметрично варьируется и длина стихов, ср.:

(12) Скачу, как бешеный, на бешеном коне; Долины, скалы, лес мелькают предо мною,

Сменяясь, как волна в потоке за волною...

Тем вихрем образов упиться - любо мне!

(А. Мицкевич: Байдарская долина)

Русская силлабика, возникшая в XVII веке в результате заимствования правил польского стихосложения, наследует его основные особенности, включая не только счет слогов и акцентную аритмию, но и обязательную женскую рифму, ибо «польские рифмы не могут иными быть, как только женскими: понеже все польские слова, выключая некоторые односложные, силу [т. е. ударение - В. М.] на предкончаемом слоге имеют» (Ломоносов 1952: 16):

(13) Монаху подобает в келии седети, Во посте молитися, нищету терпети, 
Искушения врагов силно побеждати

И похоти плотския труды умерщвляти.

(С. Полоцкий: Монах)

И здесь длина каждого стиха составляет 13 слогов, концовка каждого отмечена женской рифмой; первое вступает в конфликт с правилом ритмического альтернанса, второе - с правилом альтернанса рифменного. С точки зрения носителя русского языка силлабика, ввиду отсутствия изотонии, звучит как рифмованная проза, т. е. тяжеловесно: еще В. К. Тредиаковский указал на то, что «способ сложения стихов весьма есть различен по различию языков», а значит, не должен зависеть от произвола чуждой ему системы стихосложения. Для русского языка важна «мера стоп с падением [т. е. ударением - В. М.], приятным слуху, от чего стих стихом называется» (ТРЕдиАковский 1963: 366, 367).

\section{4. Ритм и повтор: к соотношению понятий}

В специальной литературе ритм традиционно увязывается с понятием повтора. Так, Ю. М. Лотман определяет ритм как «правильное чередование, повторяемость одинаковых элементов» (ЛотмАн 1972: 55), Л. И. Тимофеев как «систематическое, мерное повторение в стихе определенных, сходных между собой единиц речи» (ТимОФеЕВ 1982: 99). А. П. Квятковский полагает, что «всякий стих основан на системе повторности» (Квятковский 1966: 283), М. М. Гиршман трактует стихотворную речь как основанную на «принципе повтора, который охватывает и сопоставляет все элементы стиховой структуры» (ГиршмАн 1973: 161); по мнению Е. Д. Поливанова, «в основе любой системы стиха лежат фонетические повторы» (ПоливАнов 1963: 99).

Однако фонетические и иные повторы (в частности, стихомаркирующие: гомеотелевты, различные виды рифмы) не являются императивной нормой стихосложения. Необязательны они, например, в белых стихах:

(14) Пьяной горечью Фалерна

Чашу мне наполни, мальчик:

Так Постумия велела,

Председательница оргий.

(А. С. Пушкин: Мальчику - из Катулла)

Определим повтор как неоднократное использование языковой единицы (звука, морфемы, слова, словосочетания, фразы или определенной позиционной структуры) в пределах речевого отрезка. С этой точки зрения повтором следует считать различные виды параллелизма, т. е. такого построения речевой единицы, при котором каждая последующая ее часть отражает позиционную структуру предыдущей. Видом параллелизма в таком понимании является изотония, однако ни изотония, ни другие виды повтора не являются обязательной приметой синтаксического ритма (хотя могут усиливать 
его, см. 5-8). Прислушаемся к мнению Б. И. Ярхо: «Если мы возьмем исходный тип стиха - народный стих [см. 4 - В. М.], то увидим, что в нем стиховые членения совпадают с синтаксическими паузами. Это и создает стих» (Протокол 1994: 191).

Понятие повтора не лежит и в основе силлабической ритмовки, поскольку членение речевого потока на равные по числу слогов сегменты вряд ли можно считать повтором в строго терминологическом смысле данного слова.

Как видим, определение ритма через понятие повтора удалено от реалий синтаксической и силлабической ритмовки, и если принять мысль о том, что «конструктивный принцип познается не в максимуме условий, дающих его, а в минимуме» (Тынянов 1993: 31), то таким минимумом для мерной речи следует признать не повтор, а членение речевого потока на соизмеримые

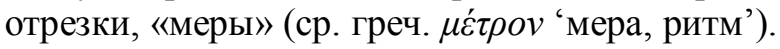

\section{5. Внутренний ритм и приемы его производства}

Считается, что «строка метрична, если она подразделена на ощутимо равные по времени части» (ANDREWS 1918: 82); давно замечено, что для стихотворной речи важен не только внешний ритм, появляющийся в результате членения текста на отдельные стихи, но и ритм внутренний, возникающий в дополнение к основному в результате стопного членения. Последнее можно «высветить»:

1) скандовкой, ${ }^{3}$ уместной, например, при озвучивании детской считалки:

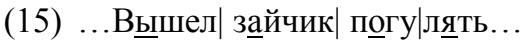

(Ф. Б. Миллер: Раз, два, три, четыре, пять...)

2) речитативнылм исполнением, «подчеркивая ритм особыми нажимами и превращая интонацию в 'распев'» (ЭйХенБАум 1969: 520):

(16) Б[у:]ря| мгл[о:]ю| н[е:]бо| кр[о:]ет...

(А. С. Пушкин: Зимний вечер)

Внутренний ритм стиха определяется также количественным и позиционным соотношением метрически ударных стоп и стоп метрически безударных, т. е. пиррихиев (ГАСПАРОВ 1997: 117-118). ${ }^{4}$ Возникает такой ритм и в результате применения цезуры (лат. caesura 'пресечение'), т. е. разделения стихотворной строки посредством специального маркера.

\footnotetext{
${ }^{3}$ При скандовке ударения «расставляются на равных интервалах, независимо от того, совпадают ли они с практически-ударяемыми слогами или нет» (ТомАшЕвский 1923: 12).

${ }^{4}$ Согласно концепции А. Белого, количеством и позиционным распределением пиррихиев определяется соотношение метра как абстрактной схемы расстановки ударений и ритма как конкретной реализации данной абстрактной схемы в речи (подробнее см. Москвин 2014: 151-174).
} 


\section{1. Вопрос о цезуре}

В основу типологии цезур могут быть положены три параметра:

1) Позиционный. По расположению в стихе различают инициальную цезуру, членящую стих ближе к его началу, медиальную, расположенную в его середине, и терминальную, стоящую ближе к концовке стиха.

2) Количественный. Еще Присциан отметил: «В стихе либо одну, либо две цезуры встречаем, реже - три» (PRISCIANI 1818: 7), т. е. «цезур может быть несколько в одном стихе» (КлАСсовСКий 1863: 12). С этой точки зрения трудно принять типовое определение цезуры как «дыхательной паузы, естественным образом разделяющей стих на полустишия» (ПоРтЕР 2003: 114).

3) Инструментальный - по приемам маркировки, т. е. выделения цезур.

Рассмотрим приемы маркировки цезур, значимые для русской поэзии. Цезуры могут возникать в результате симметричного синтаксического членения речи, нередко отмеченного пунктуационно: запятой, тире, точкой и др. Цезуры данного типа именуют синтаксическими (англ. syntactic caesura):

(17) Как эта улица зовется - | ты на дощечке прочитай, А для меня ее названье - $\|$ мой рай, потерянный мой рай.

(Е. Шварц: Как эта улица зовется...)

Такая структура сближает это двустишие с ритмическим периодом (см. 1-2 и 4-8). Полустишия, разделенные синтаксической цезурой, уподобляют колонам, цезуру - «границе между колонами в прозе» (НABINEK 1985: 186). Суть цезуры как источника внутреннего ритма обозначил византийский филолог X-XI вв. Иоанн Сикелиот, отметив, что «пресеченье стиха цезурою чрез колоны, пунктуацией отмеченные, из длинного стиха краткие делает» (IsANNOY 1834: 490), т. е. дробит ритм. Иными словами, «длинный стих» и звучать может как ряд кратких, и графически может быть разделен на «краткие стихи», ср.:

(18) Как эта улица зовется -

Ты на дощечке прочитай...

На границе колонов-полустиший, разделенных синтаксической цезурой, может происходить цезурное наращение (англ. caesural expansion) - увеличение числа безударных слогов при одном ударном:

(19) Как э|та $y \mid$ лиц $a \mid$ зове $\mid$ тся - $\|$ ты на $\mid$ доще|чке про|читай, А для $\mid$ меня $\mid$ еe $\mid$ назв $a \mid$ нье $-\|$ мой рай,, поте|рянный $\mid$ мой рай.

Последняя, усеченная стопа первого колона-полустишия встречается с первой, полной стопой второго, что приводит к цезурному наращению до трех слогов на двусложном фоне ямба. Пример цезурного наращения до четырех слогов на трехсложном фоне анапеста: 
(20) Это был|ло у мо|ря, || где ажу $\mid$ рная пе|на,

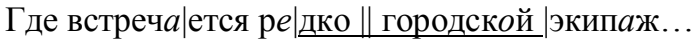

(И. Северянин: Это было у моря)

В результате цезурного наращения, замедляющего течение речи, возникает так называемый «“качельный’ размер» (ХАРджиЕв 2006: 269). Сходный эффект наблюдаем и при цзезурном усечении (англ. caesural truncation):

(21) В этих ра|скидистых |ленах || есть водо|пад вдохно|венья.

Солнце вза $\mid$ много |ч $y$ вства, $\|$ звезды и|стомы но|чной...

(И. Северянин: В кленах раскидистых)

Последняя, усеченная стопа первого колона-полустишия двусложна, а потому ритмически выделяется на трехсложном дактилическом фоне.

Определения цезуры бывают привязаны: а) к синтаксическому членению стиха; в этом случае цезура трактуется как «граница синтагмы» (DUPRIEZ 1991: 88), «членение стихотворной строки, соответствующее синтаксическому членению» (CALIFF 2002: 14); б) к пунктуации: цезура - это «разрыв или пауза в стихотворной строке, обусловленные естественным ритмом языка и усиленные пунктуацией» (CUDDON 2013: 98). Узкие трактовки, абсолютизирующие синтаксическую цезуру, не учитывают ряд приемов, описанных ниже.

К числу звуковых средств маркировки цезуры принадлежат:

1. Внутренняя, или цеезурная рифма (англ. caesural rhyme):

(22) В размышленья погруженный средь музейного добра, вдруг я замер, отраженный, в личном зеркале Петра.

(Ю. Левитанский: В оружейной палате)

Здесь цезурная рифма подчеркнута графической сегментацией, обособляющей часть стиха в отдельном подстрочии.

2. Спондей-столкновение ударных слогов:

(23) - Лети, лети, || ластынька, Лети за моря.

Прости-прощай, || Настенька, Дочушка моя.

(А. Твардовский: Страна Муравия)

3. Скопление одинаковых или сходных звуков, в частности:

а) гласных (CALIFF 2002: 204, SHIPLey 1924: 142):

(24) Это наша судьб $a, \|$ это с ней мы ругались и пели, подымались в атаку $\| u$ рвали над Бугом мосты.

(С. Гудзенко: Мое поколение) 
б) согласных (CASSERLy 1847: 73, WHITEHEAD 1930): ${ }^{5}$

(25) По холма $-\|$ круглым и смуглым, Под лучом - $\|$ сильным и пыльным, Сапожком - $\|$ робким и кротким За плащом - || рдяным и рваным.

(М. Цветаева: По холмам - круглым и смуглым...)

Чем более регулярный характер приобретают подобного рода скопления, тем более явной и убедительной представляется их колометрическая функция.

\section{4. Инометрическая вставка, роль которой могут играть:}

1) Ряд стоп, формирующий второе полустишие и метрически контрастирующий с первым. Данный прием был известен античным поэтам, в частности, «Горацию и другим лирикам, кои дактиль с ямбом перемешивали» (PRISCIANI 1818: 4-5). Так, первый стих следующего двустишия написан гекзаметром, первое полустишие второго - ямбом, второе - дактилем:

(26) Грозным ненастием свод небес затянуло: Юпитер

Низводит с неба снег и дождь; $\|$ стонут и море, и лес.

(Гораций: Эподы - перев. Н. С. Гинцбурга)

2) Отдельная инометрическая стопа: ${ }^{6}$

a) трехсложная на фоне двусложных, например, стопа дактиля на фоне хорея:

(27) Милых| глаз ее| был он| ей до|роже.

Слаще| меда он| был и| знал хо|зяйку,

Как ро|димую| мать до|чурка| знает.

(Катулл: Плачь, Венера... - перев. А. И. Пиотровского)

б) двусложная на фоне трехсложных, что наблюдаем в гекзаметре (см. 5.2).

Известны графические маркеры цезуры. Так, в старинных текстах употреблялись: а) удлиненный пробел между полустишиями; б) заглавная буква;

\footnotetext{
${ }^{5}$ Такое «стеченье согласных производит эффект, эквивалентный паузе» (CAREY 1830: 161).

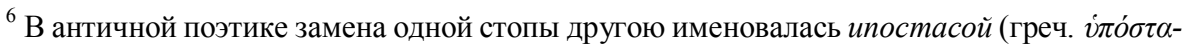
$\sigma l \varsigma$ 'подстановка'); прием ритмоизменяющего «вплетания» либо удаления слога, создающий

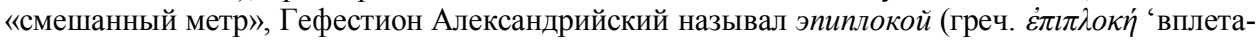

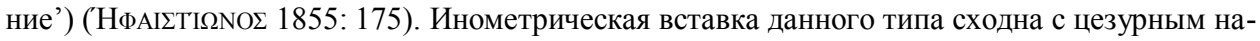
ращением и усечением (см. 19-21), но далеко не всегда связана с семантико-синтаксическим членением стиха, поэтому сходство носит здесь сугубо формальный характер.
} 
в) цезурная точка (англ. caesural dot), приподнятая над нижним срезом строки (лат. punctus elevatus), увеличенная или «изображаемая красной краской, для большей заметности» (HowARD 1815: 152): ${ }^{7}$

(28) Лета было время • мягким было солнце...

(У. Ленгленд: Видение о Петре-пахаре)

Синтаксическое членение, рифму, спондей, скопление гласных (хиатус) или согласных, инометрическую вставку и графические сигналы отнесем к числу маркеров, предусмотренных автором, а значит: а) отвечающих ритмическому замыслу текста; б) принадлежащих риторическому канону элокуциии, т. е. этапу создания текста. К числу маркеров, отвечающих исполнительскому осмыслению текста и являющихся атрибутами канона исполнения, отнесем:

1) Удлинение предцезурного звука (лат. productio ob caesuram), используемое на правах исполнительской вольности (лат. permissu poetico) (BEDAE 1975: 90), что иногда слышится и в русской речи (29a); заметим, что удлинение звука, обычно в комбинации с паузой, используется и как прием колометрического членения периода (29b):

(29a) Это наша судьб[а:], || это с ней мы ругались и пели, подымались в атак[у:] || и рвали над Бугом мосты.

(29b) Де́вицы крас[а:]вицы, || быстренько открываем

(ГудзЕнКо 2016) гл[а:]зоньки, || вставляем ч[е:]люсти...

(ПЕТРОСян 2016).

2) Декламационная, или цуезурная пауза. Еще Г. Германн указал на то, что цезура обязательно «вводит новый ритм, который, однако, должен соответствовать собственному ритму стиха, дабы не навредить ему чрезмерным рассогласованьем» (HERMANN 1817: 22). Для применения паузы должны быть определенные основания, например, наличие: а) регулярного симметричного семантико-синтаксического членения стиха (см. 17); паузу, усиливающую такое членение, называют семантической (англ. sense-pause); б) регулярного спондея (см. 23); пауза, усиливающая спондей, именуется спондеической (англ. spondaic pause). Как основание для паузирования рассматривается и нехватка дыхания: так, при исполнении гекзаметра пауза дает возможность передышки для тех, «кто одним духом тринадцати слогов прочитать не может» (Ломоносов 1952: 15). Однако физиологическая («дыхательная») пауза не всегда связана с ритмическим замыслом текста; с учетом этого факта трудно принять артикуляционные и физиологические трактовки цезуры: «Цезура есть пауза, вводимая с тем, чтобы облегчить декламацию» (KÜHNER

${ }^{7}$ Аналогом таких средств в русской поэзии представляется графическая сегментация стиха (см. 22). 
1844: 566), ср.: «Цезура представляет собою естественную паузу, соответствующую вдоху при декламации» (ARNOLD 1905: 179; ср. ПоРтеP 2003: 114).

Паузу следует считать: а) не единственным, б) факультативным (т. е. зависящим от воли исполнителя) приемом маркировки цезуры, поэтому пауза «не обязательно бывает реализована в каждом конкретном исполнении» (НABINEK 1985: 186). С этой точки зрения приемлема следующая мысль: «Цезура имеет тенденцию превращаться в паузу, но нельзя сказать, что каждая цезура есть пауза» (HARSH 1958: 239). Определяя же цезуру, согласно античной традиции, как «паузу внутри стиха» (KUIPER 2012: 93), ученые отождествляют цезуру с одним из целого ряда средств ее маркировки, т. е. «смешивают цезуру с паузой» (JАKOBSON 1979: 32); в этом случае, по образному выражению С. Бассетта, на живых «возложены мертвые руки педантов древности» (BASSETT 2003: 147).

Как известно, в трудах филологов дохристианского периода понятие цезуры не используется. Думается, данное понятие возникло в результате приложения риторического учения о периоде к стиху, что произошло, вероятнее всего, уже с началом Новой эры, когда общим местом стала следующая мысль, изложенная в трактате Магна Кассиодора: «Период есть законченное предложение, чрез пространность коего вызвано паузирование и части коего суть колоны и коммы» (CASSIODORI 1880: 146). ${ }^{8}$ С этой точки зрения логично полагать, что пространный, синтаксически усложненный стих тоже требует паузы. Так, Гермоген из Тарса отмечает: «Меняется часто в тех местах чле-

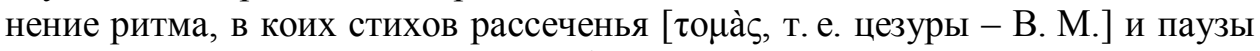
ответствуют мыслям и колонам» ('ЕрмогеNOYг 1834a: 379); более позднее предписание гласит: «В каждом длинном стихе обязательно должна быть цезура» (Рuttenham 2007: 164).

Дискуссионен вопрос об обязательности цезуры в некоторых типах стиха. Существует, например, правило, согласно которому цезура в пятистопном стихе обязательна «после второй стопы» (Квятковский 1966: 331) (см. 30a); цезура, не поддержанная маркерами, далее появляется ex analogia (30b):

(30а) Неумолим! || Он от себя прогнал

Святителей, || бояр и патриарха.

(30b) Они пред ним \| напрасно пали ниц; Его страшит || сияние престола.

(А. С. Пушкин: Борис Годунов)

Данное правило восходит к французской (силлабической) поэтике, требующей после четвертого слога в десятисложном стихе обязательной синтак-

${ }^{8} \mathrm{C}$ традицией пунктуационной и декламационной маркировки частей периода связана старинная европейская номенклатура знаков препинания и пауз: comma 'запятая', semicolon (полуко́лон) 'точка с запятой’, colon 'двоеточие', semiperiod (полупериод) 'точка, предшествующая строчной букве' и period 'точка', причем period «требует паузы, по длительности вдвое превышающей colon, colon - вдвое больше, чем semicolon и semicolon - вдвое больше, чем comma» (ADAM 1820: 222). 
сической цезуры, т. е. цезуры, которая не должна отрывать «прилагательное от существительного», «предлог от управляемой формы» (MARMONTEL 1781: 756). Однако силлабо-тоническое стихосложение вполне обеспечивает в таком стихе (за счет симметризации ударений, т. е. стопного членения, что практически невозможно в силлабике) внутреннюю ритмовку и без цезуры, поэтому для русской поэзии данное правило менее значимо. Так, поэма А. С. Пушкина «Домик в Коломне» (1830) написана уже бесцезурным пятистопным ямбом:

(31) Признаться вам, я в пятистопной строчке

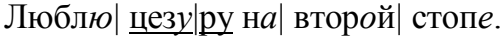

Здесь «именно слово цзезуру эту цезуру уничтожает, что явно говорит об ироническом отношении к ней автора» (ХАРЛАП 1980: 221). ${ }^{9}$ Поэт, следовавший в трагедии «Борис Годунов» рассмотренному правилу французской силлабики, признается: «Я сохранил цезурку французского пентаметра [т. е. десятисложника - В. М.] на второй стопе - и, кажется, в том ошибся, лишив добровольно свой стих свойственного ему разнообразия» (Пушкин 1962: 301).

\section{2. Вопрос о цезурной паузе в гекзаметре}

В гекзаметре (или дактило-хореическом размере, как его именовали прежде) вкрапление хореической стопы на дактилическом фоне может применяться для маркировки медиальной цезуры и (реже) начала строки, концовку же стиха стопа хорея (полная либо усеченная) маркирует обязательно, отсюда старинное правило составления гексаметрических стихов: «Дактиль до метра концовки не добегает, / Пятой стопы избегают слоги хорея» (ALDHELMI 1844: 137):

(32) Здесь я по|коюсь, Фи|липп, живо|писец на|веки бе|ссмертный, Дивная| прелесть мо|ей| кисти - у| всех на у|стах.

Душу у|мел я вдо|нуть и $\mid$ скусными| пальцами| в краски,

Набожных $\mid$ души у|мел| - голосом| бога сму|тить...

(А. Блок: Эпитафия Фра Филиппо Липпи)

Средневековые поэты, отказавшись от «тихих» инометрических вставок, стали обозначать цезуры и концовки стихов в гекзаметре с помощью рифмы средства гораздо более заметного и, с точки зрения античной поэтики, грубого. Рифмованный гекзаметр именуют леонинским (лат. hexametri leonini), ср.:

(33) Ветер лодку качает, || мальчик в ней засыпает; Вздохи ветра ленивы, $\|$ ярки волны, игривы...10

${ }^{9}$ Стиховая цезура размещается не внутри слова, а на стыке слов.

${ }^{10}$ Источник данного двустишия - латиноязычное стихотворение английского бенедиктинского монаха ХІ в. Реджинальда Scepe jacet ventus, dormit sopita juventus (ATKINS 2013: 58). 
Как показывает данное сопоставление, цезурная (т. е. внутренняя) и стихомаркирующая (т. е. концевая) рифмы функционально эквивалентны инометрической (в гекзаметре - хореической) вставке.

В настоящее время в гекзаметре принята обязательная расстановка цезурных пауз, которая подчиняется известному правилу Присциана, т. е. «реализуется на синтаксической границе» (BEEKES 1972: 9) в двух позициях: 1) после ударного или безударного слога третьей стопы (см. 34a, 34c, 34d); 2) «или, что также возможно, на четвертой стопе» (BASSETT 1925: 76) (cм. 34b):

(34а) Здесь я по|коюсь, Фи|липп, || живо|писец на|веки бе|ссмертный,

(34b) Дивная| прелесть мо $|\underline{e и ̆}|$ кисти - || у| всех на у $\mid \underline{\text { стах }} .{ }^{11}$

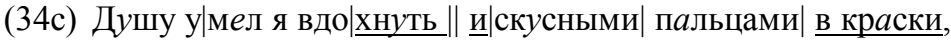

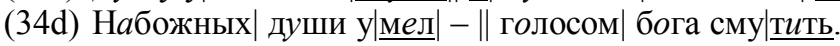

Как видим, цезурная пауза игнорирует инометрические сигналы, т. е. либо не совпадает с ними (34b), либо дублирует их (34a, 34c, 34d). Заметим, что длина гекзаметра видится античным филологам как эстетическая ценность: «Речь о предметах величественных требует удлинения колонов», поэтому «гекзаметр по своей длине приличествует героической песне и повествованию о героях», краткие же колоны «к предметам мелким применимы», их сочетание является «серым, скучным» (АнмнтРіоч 1743: 7 \& 4). Между тем, цезурная пауза, ничуть не менее заметная, чем цезурная рифма, слишком отчетливо разбивает стих на краткие колоны, по слоговому объему практически равные коммам; ${ }^{12}$ с учетом данного факта небезосновательной представляется позиция С. Бассетта, полагающего, что понятие сквозной цезурной паузы применительно к гекзаметру является «догмой античных грамматистов», которая «сковывает стихи» и «наносит им вред»; ученый считает, что «если бы во времена Аристотеля пауза производилась на третьей стопе гекзаметра независимо от смысла, то кажется невероятным, чтобы Аристотель не отметил этот факт» (ВАSSETT 2003: 145-146). В этой связи сделан, как кажется, поспешный вывод о том, что цезура - «фантастическое создание», «химера» (BASSETT 1925: 76), «плод воображения», «филологический призрак» (STURTEVANT 1924: 329). В том, что цезура представляет собой не химеру, не призрак, а реалию стихотворной речи, убеждает наличие круга рассмотренных выше средств ее маркировки.

Еще Г. Германн предложил различать цезуры обязательные и необязательные, «кои вольно понимаются» (HERMANN 1817:21). Цезурную паузу следует считать возможной при наличии элокутивных (а значит, предусмотренных автором) средств маркировки цезуры; в случае отсутствия таких средств применение паузы «становится делом индивидуального вкуса или мнения»

${ }^{11}$ Постановка цезуры на третьей стопе разрывает словосочетание моей кисти, т. е. вступает в конфликт с требованием реализации цезуры «на синтаксической границе» (BEEKES 1972: 9) и не отрывать «прилагательное от существительного» (MARMONTEL 1781: 756).

${ }^{12}$ Комма (греч. ко́ $\mu \alpha$ ‘отрезок’) - по Гермогену: краткий колон длиной от 2 до 6 слогов. 
(STEWART 1966: 32). Здесь следует помнить о том, что внутренняя ритмовка, которую пауза сообщает стиху, может не соответствовать авторскому замыслу, ибо «любая цезура обязательно меняет смысл стиха» (Рutтenнaм 2007: 164) и расстановку акцентов, «подчеркивая предцезурное слово» (cM. CLARK 1913: 62).

\section{6. Выводы}

1) Общая теория речевого ритма и трактовки данного понятия должны учитывать все три его субкатегориальных типа: а) ритм синтаксический (колонритм), б) ритм силлабический и в) ритм силлабо-тонический (изотонический).

2) С этой точки зрения целесообразно определить ритм как членение речи на соразмерные сегменты по границам синтагм (при синтаксической ритмовке) или слоговых групп (при силлабической ритмовке), а также по ударным гласным (при изотонии). Традиционная узкая трактовка ритма через понятия ударения и стопы (Аристотель, Дионисий Галикарнасский, Квинтилиан, Гефестион, А. Мейе, Г. А. Шенгели, В. Е. Холшевников и др.) сводит учение о ритме к одной из трех его разновидностей - силлабо-тоническому ритму.

3) Поскольку производство ритма возможно без поддержки повтора, определение ритма через понятие повтора (Е. Д. Поливанов, А. П. Квятковский, Л. И. Тимофеев, Ю. М. Лотман и др.) не кажется целесообразным.

4) В силлабо-тоническом стихе источниками внутреннего ритма служат стопное членение и цезура, в силлабике же, ввиду неполноты изотонической парадигмы языков, соответствующих этому типу стихосложения, - цезура. Поскольку внутренний ритм в силлаботонике обеспечивается стопным членением, цезура становится здесь средством менее значимым, чем в силлабике.

5) Цезурные маркеры следует подразделить на два типа: а) элокутивные, т. е. предусмотренные автором и отвечающие ритмическому замыслу текста (синтаксическое членение, рифма, спондей, скопление гласных или согласных, инометрическая вставка, графические сигналы: цезурная точка, punctus elevatus и др.); б) исполнительские, т. е. отвечающие исполнительскому осмыслению текста (удлинение предцезурного звука, цезурная пауза). Определение цезуры как паузы внутри стиха отождествляет цезуру с одним из средств ее маркировки, а потому нецелесообразно; употребление исполнительских маркеров (в частности, цезурной паузы) должно иметь элокутивное обоснование.

\section{Источники}

ГудзЕнко 2016 = ГудзЕнко С. «Мое поколение» в исполнении В. Высоикого. https:// vk.com/video1629287_168409330.

Петросян 2016 = ПетРоСян Е. Обход в больнище. $\mathrm{http}: / /$ zador.tv/index.php?newsid=598. 


\section{Литература}

Востоков 1817 = Востоков А. Х. Опыт о русском стихосложении. Санкт-Петербург, 1817.

ГАСПАРОВ 1997 = ГАСПАРОВ М. Л. Русский народныЙ стих и его литературные имитации. В кн.: ГАСПАРОВ М. Л. Избранные труды в 3 томах. Т. 3. Москва, 1997. 54-131.

ГиРшМАН 1973 = ГиРшМАН М. М. О ритме русской художественной прозы. В кн.: Slavic Poetics. Essays in Honor of Kiril Taranovsky. The Hague-Paris, 1973. 161-169.

Квятковский 1966 = Квятковский А. Поэтический словарь. Москва, 1966.

КлАССОВский 1863 = КлАССОвСКий В. Версификаџия. Санкт-Петербург, 1863.

Ломоносов 1952 = Ломоносов М. В. Письмо о правилах российского стихотворства. В кн.: Ломоносов М. В. Полное собрание сочинений в 10 томах. Т. 7. МоскваЛенинград, 1952. 7-18.

ЛотмАН 1972 = ЛотмАН Ю. М. Анализ поэтического текста. Ленинград, 1972.

Москвин 2014 = Москвин В. П. Теоретические основы стиховедения. Москва, 2014.

ПоливАнов 1963 = ПоливАнов Е. Д. Общий фонетический принцип всякой поэтической техники. Вопросы языкознания 1963/1: 99-112.

ПОРТЕР 2003 = ПОРТЕР Л. Г. Симметрия - владычица стихов. Очерк начал общей теории поэтических структур. Москва, 2003.

Протокол 1994 = Протокол заседания Московского лингвистического кружка 26 февраля 1923 г. Philologica 1 (1994): 191-201.

Пушкин 1962 = Пушкин А. С. Наброски предисловия к «Борису Годунову». В кн.: Пушкин А. С. Собрание сочинений в 10 томах. Т. 6. Москва, 1962. 299-302.

ТИМОФЕеВ 1958 = ТимОФЕеВ Л. И. Очерки теории и истории русского стиха. Москва, 1958.

ТИМОФЕев 1982 = ТИМОФЕеВ Л. И. СЛово в стихе. Москва, 1982.

ТОМАшЕВСКий 1923 = ТомАшЕВСКИй Б. Русское стихосложение. Метрика. Петроград, 1923.

ТРЕДИАКОВСКИЙ 1963 = ТРЕДИАКОВСКИЙ В. К. НовЫЙ и кратКий способ к сложению российских стихов. В кн.: ТРЕДИАКОВСКИй В. К. Избранные произведения. МоскваЛенинград, 1963. 365-420.

Тынянов 1993 = Тынянов Ю. Н. Литературный факт. Москва, 1993.

ХАРДЖИЕВ 2006 = ХАРДЖИЕВ Н. От Маяковского до Крученых. Москва, 2006.

ХАРЛАП 1980 = ХАРЛАП М. Г. Полемический смысл «Домика в Коломне». Известия АН СССР. Серия литературы и языка 1980/3: 219-229.

ХолшЕВНиков 1991 = ХоЛшеВников В. Е. Стиховедение и поэзия. Ленинград, 1991.

ЭЙХЕНБАУМ 1969 = ЭЙХЕНБАУМ Б. М. О поэзии. Ленинград, 1969.

ЯкоБСон 1975 = ЯкоБсон Р. О. Лингвистика и поэтика. В кн.: Структурализм: «за» и «против». Москва, 1975. 193-230.

ADAM 1820 = ADAM Alexander: The Rudiments of Latin and English Grammar. New York, 1820.

Aldhelmi 1844 = SANCTI Aldhelmi: Opera. Oxonii, 1844.

ANDREws 1918 = ANDREws Clarence E. The Writing and Reading of Verse. New York, 1918.

AQuilae 1863 = Aquilae Romani: De figuris sententiarum et elocutionis liber. Rhetores latini minores. Lipsiae, 1863. 22-37.

ARISTOTELIS 1833 = ARISTOTELIS: De rhetorica libri tres. Oxonii, 1833. 
ARNOLD $1905=$ ARnOLD Edward V. Vedic Metre in its Historical Development . Cambridge, 1905.

AtKIns 2013 = ATKIns Henry G. A History of German Versification. London, 2013.

BASSETT 1925 = BASSETT Samuel E. The caesura - a modern chimera. The Classical Weekly 18 (1925): 76-79.

Bassett 2003 = Bassett Samuel E. The Poetry of Homer. Oxford, 2003.

BEDAE 1975 = BEDAE Venerabilis: De arte metrica. Bedae Venerabilis opera I. Turnhout, 1975. 60-141.

BEEKES 1972 = BEEKES Robert: On the structure of the Greek hexameter. Glotta 50 (1972): $1-10$.

Bourassa 1993 = Bourassa Lucie: Rythme et sens. Montréal, 1993.

CALIFF 2002 = CAlifF David J. A Guide to Latin Meter and Verse Composition. London, 2002.

Carey 1830 = Carey John: Latin Prosody Made Easy. London, 1830.

Carmen 1863 = Carmen de figures vel schematibus. In: Rhetores latini minores. Lipsiae, 1863. 63-70.

Casserly 1847 = Casserly Patrick S. A Complete System of Latin Prosody. New York, 1847.

CASSIOdORi $1880=$ CAssiodori Magnii Avrelii: De orthographia liber. Grammatici Latini . T. 7. Lipsiae, 1880. 143-210.

CERIANI 1988 = CERIANI Giulia: L'empreinte rythmique: régulation, information, contraintes. Cahiers de sémiotique textuelle 14 (1988): 37-47.

CiCERONIS $1824=$ CiCERONIS M. T. De oratore libri tres. Londini, 1824.

Ciceronis 1828 = Ciceronis M. T. Rhetoricorum ad Herennium. Lipsiae, 1828.

CLARK 1913 = CLARK Frank: Caesural emphasis in the Iliad. The Classical Journal 9 (1913): 61-66.

COOPER 1998 = COOPER Gordon B. Mysterious Music. Rhythm and Free Verse. Stanford, 1998.

Cuddon $2013=$ Cuddon John A. Dictionary of Literary Terms and Literary Theory. Oxford, 2013.

Dessons-Meschonnic 1998 = Dessons Gérard, Meschonnic Henri: Traité du rythme. Des vers et des proses. Paris, 1998.

DionYsir 1774 = DionYsiI Halicarnassensis: De admiranda vi dicendi in Demosthene. Dionysii Halicarnassensis Opera omnia graece et latine. Vol. 6. Lipsiae, 1774. 953-1169.

DuprIEZ 1991 = DupriEz Bernard: A Dictionary of Literary Devices. Toronto-Buffalo, 1991.

Goodell 1901 = Goodell Thomas D. Chapters on Greek Metric. New York-London, 1901.

HABINEK 1985 = HaBINEK Thomas N. The Colometry of Latin Prose. Berkeley-Los Angeles-London, 1985.

HARSH 1958 = HARSH Philip W. Early Latin Meter and Prosody (1935-1955). Lustrum 3 (1958): 215-250.

HERMANN 1817 = HERMANN Gottfried: Elementa doctrince metricce. Glasguæ, 1817.

Hobsbaum 1996 = Hobsbaum Philip: Metre, Rhythm and Verse Form. London-New York, 1996.

HOWARD $1815=$ HOWARD Henry: A dissertation on the state of English poetry before the sixteenth century. The Works of Henry Howard Earl of Surrey. Vol. 1. London, 1815. 137-286. 
JAKOBSON 1979 = JAKOBSON Roman: O чешском стихе - преимущественно в сопоставлении с русским. In: JАKOBSON Roman: Selected Writings. Vol. 5. On Verse, its Masters and Explorers. The Hague-Paris-New York, 1979. 3-130.

KÜHNER 1844 = KüHNER Raphael: Grammar of the Greek Language. New York, 1844.

KUIPER 2012 = KUIPER Kathleen: Poetry and Drama. Literary Terms and Concepts. New York, 2012.

LANHAM 2003 = LANHAM Richard: Analyzing Prose. London-New York, 2003.

MARMONTEL 1781 = MARMONTEL Jean-François: Césure. In: Encyclopédie ou dictionnaire raisonné des sciences des arts et des métiers. Vol. 6. Lausanne-Bern, 1781. 755-758.

MeIllet 1923 = MeIllet Antoine: Les origines indo-européennes des mètres grecs. Paris, 1923.

PRISCIANI 1818 = PRISCIANI: Opera minora . Lugduni Batavorum, 1818.

Puttenham 2007 = Puttenham George: The Art of English Poesy. Ithaca-London, 2007.

QuintIliani 1725 = Marci Fabil Quintiliani: De oratoria institutione. Parisiis, 1725.

SCHILLER 1961 = SCHILLER Andrew: An approach to Whitman's metrics. Emerson Society Quarterly 22 (1961): 23-25.

SHIPLEY 1924 = SHIPLEY Frederick W. Hiatus, elision, caesura in Virgil's hexameter. Transactions and Proceedings of the American Philological Association 55 (1924): 137-158.

STEWART 1966 = STEWART George R. The Technique of English Verse. New York, 1966.

STURTEVANT 1924 = STURTEVANT Edgar H. The doctrine of caesura, a philological ghost. American Journal of Philology 45 (1924): 329-350.

TZETZIS 1837 = TzETZIS: Scholia in Hermogenem. In: Anecdota Graca e codd. manuscriptis Bibliothecarum Oxoniensium. Vol. 4. Oxonii, 1837. 1-148.

WhitehEAd $1930=$ WhiteheAd Philip B. A new method of investigating the caesura in Latin hexameter and pentameter. American Journal of Philology 51 (1930): 358-371.

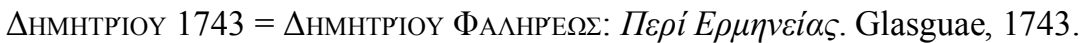

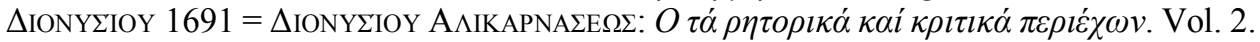
Lipsiae, 1691.

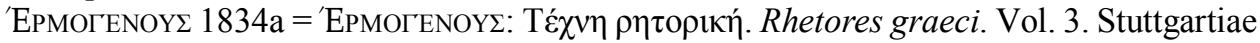
et al., 1834. 1-445.

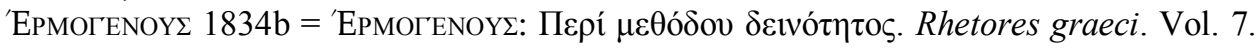
Stuttgartiae et al., 1834. 1090-1352.

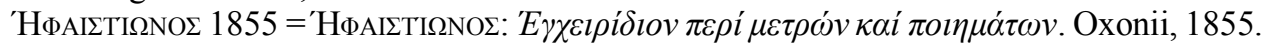

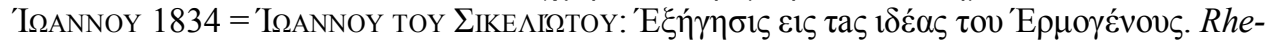
tores Graeci. Vol. 6. Stuttgartiae et al., 1834. 56-504. 